\title{
High Prevalence of Mutations of the p53 Gene in Poorly Differentiated Human Thyroid Carcinomas
}

\author{
James A. Fagin, * Keiichi Matsuo, ${ }^{\star \dagger}$ Amitabha Karmakar, ${ }^{\star}$ Dan Lin Chen, ${ }^{\star}$ Shih-Huey Tang, ${ }^{\star}$ and H. Phillip Koeffler \\ ${ }^{*}$ Divisions of Endocrinology and ${ }^{\ddagger}$ Hematology-Oncology, Cedars-Sinai Medical Center, \\ UCLA School of Medicine, Los Angeles, California 90048
}

\begin{abstract}
The development and progression of thyroid tumors is signaled by phenotype-specific mutations of genes involved in growth control. Molecular events associated with undifferentiated thyroid cancer are not known. We examined normal, benign, and malignant thyroid tissue for structural abnormalities of the p53 tumor suppressor gene. Mutations were detected by singlestrand conformation polymorphisms of PCR-amplified DNA, using primers bracketing the known hot spots on either exons $5,6,7$, or 8 . The prevalence of mutations was as follows: normal thyroid $0 / 6$; follicular adenomas $0 / 31$; papillary carcinomas $0 / 37$; medullary carcinomas $0 / 2$; follicular carcinomas 1/11; anaplastic carcinomas 5/6; thyroid carcinoma cell lines $3 / 4$. Positive cases were confirmed by direct sequencing of the PCR products. All five anaplastic carcinoma tissues and the anaplastic carcinoma cell line ARO had G:C to A:T transitions leading to an Arg to His substitution at codon 273. In both tumors and cell lines, examples of heterozygous and homozygous p53 mutations were identified. The only thyroid carcinoma cell line in which p53 mutations were not detected in exons 5-8 had markedly decreased p53 mRNA levels, suggesting the presence of a structural abnormality of either p53 itself or of some factor controlling its expression. The presence of p53 mutations almost exclusively in poorly differentiated thyroid tumors and thyroid cancer cell lines suggests that inactivation of p53 may confer these neoplasms with aggressive properties, and further loss of differentiated function. (J. Clin. Invest. 1993. 91:179184.) Key words: anaplastic carcinoma $\bullet$ mutation $\bullet$ p53 nuclear protein • thyroid neoplasms • tumor suppressor gene • tumorigenesis
\end{abstract}

\section{Introduction}

Thyroid nodules develop in up to $10 \%$ of adults during their lifetime. Presently available diagnostic approaches often do not discriminate benign from malignant follicular neoplasms preoperatively, nor do they accurately predict clinical behavior. Tumors of follicular thyroid cells represent an interesting model of epithelial cell transformation. They comprise a broad spectrum of neoplastic phenotypes, which include benign and

\footnotetext{
$\dagger$ Dr. Matsuo died on 9 July 1992.

Address reprint requests to Dr. Fagin, Division of Endocrinology, Cedars-Sinai Medical Center, Becker Building 131, 8700 Beverly Blvd., Los Angeles, CA 90048. 1992.

Received for publication 18 May 1992 and in revised form 3 August
}

J. Clin. Invest.

(C) The American Society for Clinical Investigation, Inc. $0021-9738 / 93 / 01 / 0179 / 06 \$ 2.00$

Volume 91, January 1993, 179-184 nonprogressive macrofollicular adenomas, microfollicular adenomas, well-differentiated follicular and papillary carcinomas, and the invasive and always fatal anaplastic carcinomas (1). The sequence of somatic cell mutations which underlie these different tumor cell types is gradually becoming unraveled (29). Activating point mutations of ras oncogenes are probably an early event in thyroid tumor formation, in that they occur with similar prevalence in benign and malignant thyroid tumors (3-6). Allelic losses of chromosome 11 q13, a region containing a number of genes involved in growth control, including the putative gene predisposing to multiple endocrine neoplasia type I, are found in follicular but not papillary thyroid tumors (7), suggesting that loss of a tumor suppressor gene at this locus may direct progression towards the follicular phenotype. In contrast, the PTC oncogene, which results from an intrachromosomal inversion in $10 \mathrm{q}$, leads to the activation of the ret proto-oncogene and is unique to papillary carcinomas (8). Recently, Herrmann et al. (9) reported loss of heterozygosity for loci on chromosome $3 p$ associated with follicular carcinomas. No information exists concerning either the molecular genetics of anaplastic thyroid carcinomas, or events which may be involved in the transition to this aggressive form of the disease.

p53 is a nuclear protein which appears to play a role in the regulatory control of normal cellular proliferation (10). Recent studies suggest that p53 may act as a tumor suppressor gene. Allelic deletions of the p53 locus on chromosome $17 p$ are highly prevalent in colonic carcinomas, with the other p53 allele often harboring point mutations $(11,12)$. Mutations of p53 have been reported to occur with high frequency in other cancer types, including lymphomas, leukemias, and cancers of lung, esophagus, breast, liver, bone, bladder, ovary, and brain (13-23). Ledent et al. (24) recently observed that mice harboring a thyroglobulin-SV40 large and small $\mathrm{T}$ antigen transgene-developed thyroid tumors with a markedly dedifferentiated, anaplastic-like phenotype. Because SV40 large T antigen is known to associate and possibly functionally inactivate $\mathrm{p} 53(25,26)$, we postulated that mutations of $\mathrm{p} 53$ may play a role in determining progression to an aggressive, dedifferentiated neoplastic phenotype in human thyroid tumors. In this study we examined the DNA of benign and malignant thyroid neoplasms, and that of four poorly differentiated thyroid carcinoma cell lines, for mutations in previously reported "hot spots" of the p53 gene. We observed that mutations are confined to dedifferentiated thyroid cancers and cancer cell lines, in which they occur with high frequency.

\section{Methods}

Tissues and cell lines. Human thyroid tissues were obtained at the time of surgery and immediately frozen in liquid $\mathrm{N}_{2}$ until assayed. Whenever possible, samples were taken from both the tumor and the normal 


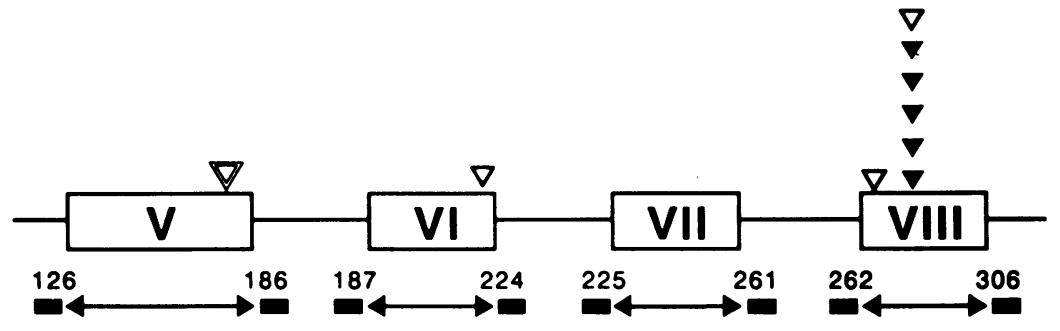

Figure 1. Regions of the p53 gene amplified and subjected to SSCP analysis. Numbers flanking the exons indicate the aminoacid positions. Primers (black bars) were designed to bracket the indicated exons (5-8). Position of mutations is indicated by inverted triangles. $\nabla$ (codon 273): anaplastic carcinomas; $\Delta$ (codons 223, 266 and 273): thyroid carcinoma cell lines; $\nabla$ $\checkmark$ (173): follicular carcinoma. thyroid from each individual. Two undifferentiated human thyroid carcinoma cell lines (ARO and FRO), one poorly differentiated papillary carcinoma cell line (NPA), and one follicular carcinoma cell line (WRO) $(27,28)$ were generously provided by Dr. Guy Juillard (UCLA), and maintained in RPMI-1640 supplemented with $10 \%$ fetal calf serum, $100 \mu \mathrm{M}$ nonessential aminoacids, and $0.13 \mathrm{mg} / \mathrm{ml} \mathrm{Na}$ pyruvate.

Nucleic acid extraction. RNA and DNA were extracted from a cesium chloride ultracentrifugation gradient as described (29). The RNA pellet was rinsed in $80 \%$ ethanol and then resuspended in diethylpyrocarbonate-treated $\mathrm{H}_{2} \mathrm{O}$. The DNA layer was immediately precipitated in $2.5 \mathrm{vol}$ of ethanol and recovered by spooling. The DNA pellet was then rinsed in $10 \mathrm{ml}$ of $80 \%$ ethanol and recovered by centrifugation at $3,000 \mathrm{~g}$ at room temperature. DNA was then digested at $55^{\circ} \mathrm{C}$ overnight with $1 \mathrm{mg} / \mathrm{ml}$ proteinase $\mathrm{K}$ in a buffer containing $150 \mathrm{mM} \mathrm{NaCl}$, $10 \mathrm{mM}$ Tris, $\mathrm{pH} 7.5,10 \mathrm{mM}$ ethylene diaminotetraacetic acid (EDTA), and $0.5 \%$ sodium dodecyl sulfate (SDS). The mixture was then phenol-chloroform extracted. Sodium acetate (final concentration $0.3 \mathrm{M}$ ) was added to the aqueous layer, which was then ethanol precipitated. DNA was pelleted, air-dried, and resuspended in $\mathrm{H}_{2} \mathrm{O}$. After quantification by absorption at $260 \mathrm{~nm}$, extracts were stored until assayed (RNA at $-70^{\circ} \mathrm{C}$, DNA at $-20^{\circ} \mathrm{C}$ ). For extraction of DNA from paraffin-embedded anaplastic carcinomas, $60 \mu \mathrm{M}$ sections were deparaffinized in $0.5 \mathrm{ml}$ of xylene, and then ethanol precipitated. Samples were incubated in $100 \mathrm{mM}$ Tris $\mathrm{Cl}, 4 \mathrm{mM}$ EDTA, pH 8.0, and 1 $\mathrm{mg} / \mathrm{ml}$ proteinase $\mathrm{K}$ for $12 \mathrm{~h}$ at $37^{\circ} \mathrm{C}$, boiled for $7 \mathrm{~min}$, and microfuged to remove residual material. $1-10-\mu l$ aliquots were used as templates for polymerase chain reaction (PCR). ${ }^{1}$

Northern gel electrophoresis. Gel electrophoresis of $20 \mu \mathrm{g}$ of total RNA was performed on $1 \%$ agarose gels containing $2.2 \mathrm{M}$ formaldehyde, as previously described (30). The filters were hybridized in a buffer containing $50 \%$ formamide, $5 \times$ SSPE $(43.8 \mathrm{~g} /$ liter $\mathrm{NaCl}, 6.9$ $\mathrm{g} /$ liter NaH2PO4-H20, and $1.85 \mathrm{~g}$ /liter EDTA), $5 \times$ Denhardt's solution ( $1 \mathrm{~g}$ /liter polyvinyl-pyrrolidone, $1 \mathrm{~g} /$ liter bovine serum albumin, and $1 \mathrm{~g} /$ liter Ficoll 400 ), $0.1 \%$ SDS, and $200 \mu \mathrm{g} / \mathrm{ml}$ salmon sperm DNA for $48 \mathrm{~h}$ at $42^{\circ} \mathrm{C}$ with ${ }^{32} \mathrm{P}$-labeled DNA probes. Probes were labeled with $\left[\alpha^{32} \mathrm{P}\right] \mathrm{dCTP}$ using the random primer technique (31) following the manufacturer's protocol (Stratagene, Inc., La Jolla, CA). The following human probes were used: $\mathrm{p} 53$ cDNA pR42 (Nco 500-bp fragment) (32), $\gamma$-actin cDNA pHF $\gamma$-A-1 (33). After hybridization the filters were washed twice in $2 \times \mathrm{SSC}(0.3 \mathrm{M} \mathrm{NaCl}$ and $30 \mathrm{mM}$ sodium citrate), $0.1 \%$ SDS at room temperature, and then twice in $0.1 \times \mathrm{SSC}, 0.1 \%$ SDS at $55^{\circ} \mathrm{C}$. Blots were then exposed to XAR -5 film (Eastman Kodak Co., Rochester, NY) for autoradiography for 12-72 h at $-70^{\circ} \mathrm{C}$.

Single-strand conformation polymorphism (SSCP) analysis. SSCP analysis was performed using a modification of a previously reported method $(34,35)$. DNA specimens were coded, and the operator was blinded to the histological diagnoses of the samples. Briefly, PCR was performed with $200 \mathrm{ng}$ of genomic DNA, $10 \mathrm{pmol}$ of each primer, 200 $\mu \mathrm{M}$ dNTPs, $1 \mu \mathrm{Ci}$ of $\left[\alpha-{ }^{32} \mathrm{P}\right] \mathrm{dCTP}$ (ICN, sp act $3,000 \mathrm{Ci} / \mathrm{mmol}$ ) 10 $\mathrm{mM}$ Tris $\mathrm{HCl}$, pH 8.3, $50 \mathrm{mM} \mathrm{KCl}, 1.5 \mathrm{mM} \mathrm{MgCl} 2,0.1 \mathrm{mg} / \mathrm{ml}$ gelatin, and $0.5 \mathrm{U}$ of Taq DNA polymerase (Ampli Taq, Cetus Corp., Emery-

1. Abbreviations used in this paper: $\mathrm{PCR}$, polymerase chain reaction; SSCP, single-strand conformational polymorphism. ville, CA ) in a final volume of $20 \mu \mathrm{l} .35$ cycles of denaturation $\left(94^{\circ} \mathrm{C}\right)$, annealing $\left(55^{\circ} \mathrm{C}\right)$, and extension $\left(72^{\circ} \mathrm{C}\right)$ were conducted on an automated heat block (DNA thermal cycler; Perkin-Elmer Cetus, Norwalk, CT). The reaction mixture $(2 \mu \mathrm{l})$ was diluted 1:10 in DNA gel loading buffer ( $96 \%$ formamide, $20 \mathrm{mM}$ EDTA, $0.05 \%$ bromophenol blue, and $0.05 \%$ xylene cyanol). Samples were heated at $90^{\circ} \mathrm{C}$ for $4 \mathrm{~min}$, chilled on ice, and immediately loaded $(2.5 \mu \mathrm{l})$ onto a $6 \%$ acrylamide $/ 0.5 \times$ $0.5 \mathrm{M}$ Tris, $0.5 \mathrm{M}$ boric acid, $1 \mathrm{mM}$ EDTA gel containing $10 \%$ (vol/ vol) glycerol. Gels were run at $300 \mathrm{~V}$ for $12-18 \mathrm{~h}$ at room temperature. Autoradiography was performed with an intensifying screen for 6-48 h.

Oligonucleotide primers. Sequences of p53 intronic primers bracketing exons 5, 6, 7, and 8 were derived from published reports (36; Fig. 1):

Exon 5: 5' primer (sense, E5I4) 5' ATC TGT TCA CTT GTG CCC TGA CTT TC $3^{\prime} ; 3^{\prime}$ primer (antisense, E5I5) 5' ACC CTG GGC AAC CAG CCC TGT C $3^{\prime}$.

Exon 6: 5' primer (sense, E6I5) 5' CAG GGC TGG TTG CCC A 3'; 3' primer (antisense, E6I6) 5' ACT GAC AAC CAC CCT TAA CCC CTC 3'.

Exon 7: 5' primer (sense, E7 19) 5' CTC CTA GGT TGG CTC TG 3'; 3' primer (antisense, E7I7) 5' GAG GCT GGG GCA CAG CAG GCC AGT G 3'.

Exon 8: 5' Primer (sense, E8I7) 5' TAG GAC CTG CTG ATT TCC TTA CTG CCT 3'; 3' primer (antisense, E8I8) 5' AAC TGC ACC CTT GGT CTC CAC C 3'.

Direct sequencing. Direct sequencing of the PCR products was done using the Sequenase Kit (U.S. Biochemicals, Cleveland, $\mathrm{OH}$ ) with $T_{7}$ polymerase, after making the PCR product single-stranded with $T_{7}$ exonuclease (U.S. Biochemicals).

\section{Results}

About $98 \%$ of single base-substitution mutations of the coding region of p53 in human cancers occur within a 540-bp stretch between codons 126-306, corresponding to exons 5-8 (37). DNA from thyroid tissues and thyroid cancer cell lines was screened for mutations within this region by SSCP. Intronic primers flanking the individual exons were used to amplify the template DNA in the presence of $\left[{ }^{32}\right.$-P $]$ CTP (Fig. 1). SSCP analysis of four clonal human thyroid cancer cell lines is shown in Fig. $2 \mathrm{~A}$. Positive samples showed a shift in mobility of one of the labeled strands. In certain cases, SSCP analysis can simultaneously establish whether a sample has lost one allele and harbors a mutation in the remaining one (34). This is particularly applicable to clonal cell lines. In the SSCP analysis for exon 8, one of the separated strands from the ARO anaplastic carcinoma cell line migrates abnormally, and this is associated with complete disappearance of one of the normal bands (lane 1). This is compatible with a homozygous mutation of $\mathrm{p} 53$, with one allele being lost and the other mutated. Similarly, the WRO follicular carcinoma cell line has an abnormally migrating exon 6 fragment and appears to have lost the wild-type copy 
EXON 5

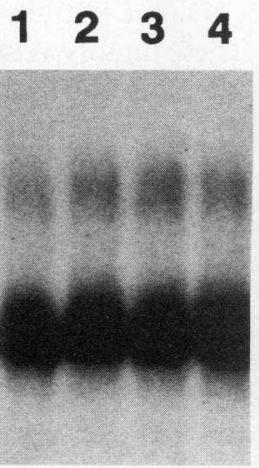

EXON 6

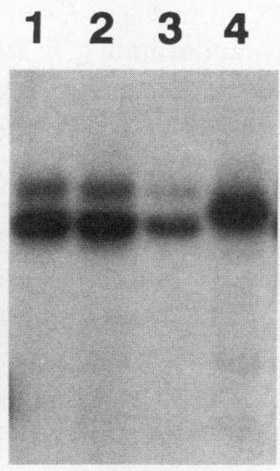

EXON 7
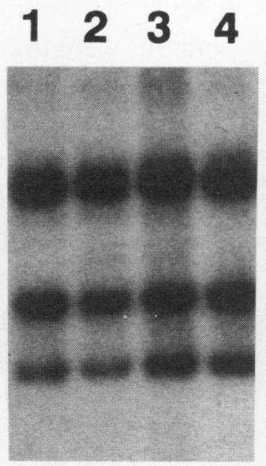

EXON 8
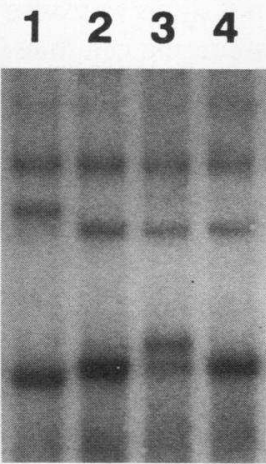

\section{$\begin{array}{lllllllllllll}1 & 2 & 3 & 4 & 5 & 6 & 7 & 8 & 9 & 10 & 11 & 12 & 13\end{array}$}

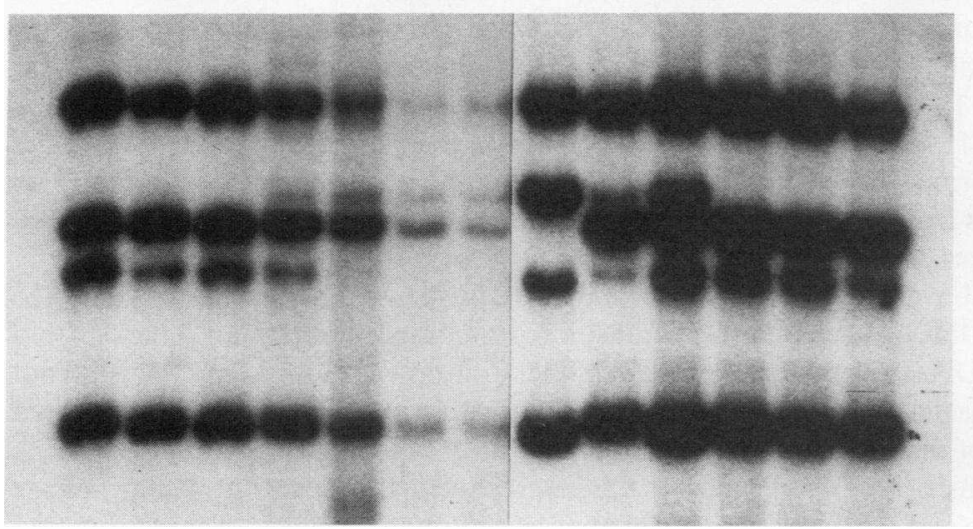

Figure 2. (Top) SSCP analysis of genomic DNA of human thyroid carcinoma cell lines using primers flanking each of exons 5-8. Lane 1; ARO (anaplastic carcinoma); Lane 2; FRO (anaplastic carcinoma); Lane 3; NPA (papillary adenocarcinoma); Lane 4; WRO (follicular carcinoma). WRO cell DNA has a strand shift for exon 6. ARO and NPA cell DNA have altered migration patterns with primers bracketing exon 8 . (Bottom) Exon 8 SSCP analysis for anaplastic thyroid carcinoma tissues and ARO cell line. Lanes 1-3, 11-13; normal controls; Lanes 4-7; anaplastic carcinomas (from paraffin blocks); Lanes 9, 10; J9 anaplastic carcinoma (fresh tissue); Lane 8; ARO cell line. A strand shift is present in lanes 4-10. of $\mathrm{p} 53$. In contrast, SSCP-analysis of the poorly differentiated papillary carcinoma cell line NPA (Fig. $2 A$, exon 8 ) reveals one strand with a migration shift, but all normal bands are also present. This suggests that both a wild-type allele and a mutated copy of p53 exist in these cells.

A representative experiment for exon 8 SSCP analysis of human thyroid cancer tissues is shown in Fig. 2 B. DNA samples from five anaplastic carcinoma tissues showed abnormally migrating bands in addition to the normal strands (lanes 4-7 and 10). This cannot be taken as evidence for the presence of a wild-type copy of p53 in the tumor cells, as the normal bands may have derived from contaminating normal tissue DNA within the tumor specimen. PCR-amplified DNA from all SSCP-positive samples was sequenced. Interestingly, all anaplastic carcinoma tissues as well as the anaplastic carcinoma cell line ARO contained a CGT to CÁT transition at codon 273, leading to an Arg to His substitution.

Prevalence of p53 mutations in thyroid tumors and cell lines of various phenotypes is summarized in Table I. None of either the normal thyroid specimens or the follicular adenomas harbored p53 mutations. Differentiated thyroid carcinomas were also largely unaffected: $0 / 37$ papillary carcinomas and

Table I. Prevalence of p53 Mutations in Human Thyroid Carcinoma Tissues and Cell Lines

\begin{tabular}{|c|c|c|c|c|}
\hline Tissue & \multirow{2}{*}{$\begin{array}{c}\text { Prevalence } \\
0 / 7\end{array}$} & \multirow[t]{2}{*}{ Codon } & \multicolumn{2}{|r|}{ Mutation } \\
\hline Normal thyroid & & & & \\
\hline Follicular adenomas & $0 / 31$ & & & \\
\hline Papillary carcinomas & $0 / 37$ & & & \\
\hline Medullary carcinomas & $0 / 2$ & & & \\
\hline Follicular carcinomas & $1 / 11$ & 173 & GTG (Val) & TTG (Leu) \\
\hline Anaplastic carcinomas & $5 / 6$ & 273 & CGT (Arg) & $\mathrm{CAT}$ (His) $\quad(n=5)$ \\
\hline \multicolumn{5}{|l|}{ Thyroid carcinoma } \\
\hline cell lines & $3 / 4$ & & & \\
\hline \multicolumn{2}{|c|}{ ARO (anaplastic) } & 273 & CGT (Arg) & CAT (His) \\
\hline \multicolumn{2}{|c|}{ WRO (follicular) } & 223 & CC.T (Pro) & CTT (Leu) \\
\hline \multicolumn{2}{|c|}{ NPA (papillary) } & 266 & GGA (Gly) & GTA (Glu) \\
\hline
\end{tabular}


1/11 follicular carcinomas had detectable p53 abnormalities. In marked contrast, 5/6 anaplastic carcinomas had a point mutation at codon 273. Base substitution mutations were also identified in three of four clonal thyroid carcinoma cell lines. Of note is that $7 / 9$ positive cases involved G:C to A:T transitions. In addition, all anaplastic carcinomas and the ARO anaplastic carcinoma cell line were mutated at a $\mathrm{CpG}$ mutational hot spot. Interestingly, FRO cells, derived from a patient with a large cell undifferentiated thyroid carcinoma, and which was the only cell line that did not appear to have p53 abnormalities (exons 5-8) as detected by SSCP, had markedly decreased p53 mRNA content (Fig. 3).

\section{Discussion}

To obtain evidence for a role of tumor suppressor genes in human thyroid tumorigenesis, we recently reported studies on a large number of thyroid tumors screened for loss of genetic material using highly polymorphic markers for serveral nonacrocentric chromosome arms. Contrary to observations in other forms of neoplasia, we found a low prevalence of genetic loss, which was largely confined to a locus on chromosome 11 q13 in follicular neoplasms (7). Interestingly, none of the 33 informative cases of benign and differentiated thyroid neoplasms had loss of heterozygosity for the chromosome $17 p$ marker YNZ22, which is closely adjacent to the p53 gene. In the above study, anaplastic carcinomas and thyroid carcinoma cell lines were not examined because of a lack of constitutional DNA from the affected individuals. We were prompted to consider further a role for p53 in anaplastic carcinomas because of the high prevalence of mutations of this gene in other forms of aggressive cancer. In addition, mice expressing SV40 large and small $\mathrm{T}$ antigen transgenes in thyroid cells have been reported to develop undifferentiated carcinomas (24), further suggesting a role for $\mathrm{p} 53$ in malignant thyroid cancer.

We used SSCP analysis to screen for base substitution mutations (34). None of the benign follicular adenomas and differentiated papillary carcinomas and only $1 / 11$ follicular carcinomas had $\mathrm{p} 53$ abnormalities by SSCP. In contrast, we found altered p53 strand migration patterns confined almost exclusively to poorly differentiated thyroid carcinomas and thyroid carcinoma cell lines. A singular feature was that all positive anaplastic carcinomas and the anaplastic carcinoma cell line ARO had codon $273 \mathrm{G}: \mathrm{C}$ to A:T transitions. As opposed to ras oncogenes, which are also frequent targets of mutations in neoplasia, p53 mutations in human cancers occur at multiple sites

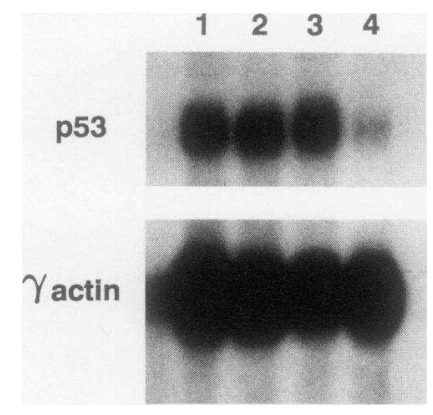

Figure 3. Northern blots of RNA from clonal thyroid carcinoma cell lines hybridized with p53 (upper panel), and gamma actin cDNA probes (lower panel). Lane 1; NPA (papillary adenocarcinoma); Lane 2; WRO (follicular carcinoma); Lane 3; ARO (anaplastic carcinoma); Lane 4; FRO (anaplastic carcinoma). p53 mRNA is $2.6 \mathrm{~kb}, \gamma$-actin is $2.1 \mathrm{~kb}$. FRO cells had mark-

edly decreased p53 mRNA abundance. All cell lines but FRO had p53 point mutations (Table I). in the evolutionarily conserved domains of the protein (37). A remarkable exception to this pattern has been reported in hepatocellular carcinomas, in which G:C to T:A codon 249 transversions were highly predominant $(19,20)$. These tumors were from patients from geographical regions where aflatoxin $B 1$ is a common food contaminant. This carcinogen causes frequent $G$ to $T$ transversions in mutational assays, and could account for the selectivity of p53 mutations in hepatocellular carcinomas. In non-small cell lung cancer, p53 G:C to T:A transversions were also common, but these were distributed among many different codons $(37,38)$. Of note is that environmental carcinogens, such as benzo(a)pyrene present in tobacco smoke, are associated with $\mathrm{G}$ to $\mathrm{T}$ transversions (39).

DNA mutations can arise through two major pathways. Firstly, they may be caused by exogenous factors, in which the environmental agent determines the nature of DNA damage. Alternatively, they may result from errors in mechanisms controlling metabolism of nucleic acids. $\mathrm{CpG}$ dinucleotides are frequent targets of this latter type of mutation (40). The transition observed in all positive anaplastic thyroid carcinoma samples involved a $\mathrm{CpG}$ mutation. Because the cytosine in the CpG dinucleotide on codon 273 has been found to be methylated in vivo (41), the high mutation rate at this site in these tumors could be due to deamination of the methylated cytosine and replacement by a thymidine (41).

While this work was in progress, Wright et al. (42) reported a codon 273 transitional mutation in a human follicular thyroid carcinoma cell line. Contrary to our findings, they did not encounter p53 mutations within exons 5,7 , and 8 , or increased p53 immunostaining in any of four anaplastic carcinomas. The significance of this discrepancy is unclear, but could indicate true regional differences, confounding effects of contamination with normal cells within the tissue sections, or mutations at other sites in the gene (i.e., exon 6) which were not examined.

Mutations in different locations of p53 may lead to distinct biological effects. The allele mutant for residue 175 is $3-10$ fold more efficient than the mutant for residue 273 in cooperating with ras to transform primary rat cells in culture $(10,43)$. The p53 mutants at residues 135 and 175 also show evidence of changes in $\mathrm{p} 53$ protein conformation, in that they are not recognized by specific monoclonal antibodies, and they form complexes with heat shock protein 70 , whereas mutant 273 does not $(10,44)$. There is controversy as to whether various mutant p53 proteins may also differ in their ability to activate transcription $(45,46)$. However, Kern et al. (46) recently reported that several p53 mutants, including that for codon 273 , showed loss of transcriptional activity due to impairment of p53 binding to specific DNA rerognition sequences. The predilection for codon 273 mutations of p53 in undifferentiated thyroid carcinomas may therefore result in specific biological consequences. For instance, this mutation conceivably may confer growth advantage to cells harboring mutations of oncogenes other than ras. This is potentially significant, in that 20$50 \%$ of follicular neoplasms harbor ras mutations (3-6).

The identity of p53 as a tumor suppressor gene is supported from the study of human tumors. Neoplasms showing loss of one p53 allele and mutation of the other are common, and could be considered to have a complete impairment in p53 function. However, a number of tumors are being identified in which a mutant allele is coexpressed with wild-type p53, consistent with a dominant negative effect of the defective protein 


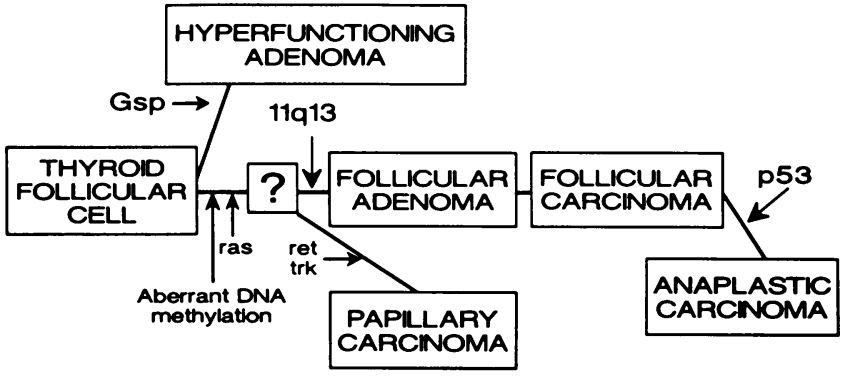

Figure 4. Molecular events in thyroid neoplasia. Point mutations of ras oncogenes are equally prevalent in benign and malignant thyroid neoplasms. Mutational activation of tyrosine kinase oncogenes ( ret, $t r k$ ) are unique to papillary adenocarcinomas. Loss of sequences on chromosome 11q13 occur in follicular, but not papillary neoplasms. p53 mutations are associated with the transition to anaplastic carcinomas.

$(10,23,47)$. The ARO and NPA thyroid carcinoma cell lines represent examples of the former and latter, respectively, and suggest that both these p53 mutation profiles can provide growth advantage to thyroid tumor cells.

Over the past few years, a pattern of sequential mutational events which may underlie initiation and progression of thyroid neoplasia is becoming apparent (2-9). The model proposed by Fearon and Vogelstein (48) for colon tumorigenesis appears to be also applicable to thyroid neoplasms, although the genes involved in the phenotypic progression differ (Fig. 4). The studies described in this paper indicate that mutational inactivation of $\mathrm{p} 53$ is probably responsible for the progression to the most malignant form of this disease.

\section{Acknowledgments}

We are grateful to the following for providing us with tissue samples: Drs. Alfred Katz, Nathan Friedman, and members of the Pathology Department at Cedars-Sinai Medical Center; Dr. Raul Gutman (Hospital Italiano, Buenos Aires, Argentina); Dr. Kalman Kovacs (Mc Gill University, Toronto, Canada ); and Drs. Naohumi Ishikawa and Kunihiko Ito (Ito Hospital, Tokyo, Japan ). We are also indebted to Dr. Guy Juillard (U.C.L.A.) for generously providing the clonal human thyroid carcinoma cell lines. We dedicate this paper to the memory of Dr. Keiichi Matsuo, who tragically died while this manuscript was in review.

This study was supported by National Institutes of Health grants CA-50706 and DK-42792.

\section{References}

1. Livolsi, V. A. 1990. Surgical Pathology of the Thyroid, 2nd edition. W. B. Saunders, Philadelphia. 131-383.

2. Namba, H., K. Matsuo, and J. A. Fagin. 1990. Clonal composition of benign and malignant human thyroid tumors. J. Clin. Invest. 86:120-125.

3. Lemoine, N. R., E. S. Mayall, F. S. Wyllie, E. D. Williams, M. Goyns, B. Stringer, and D. Wynford-Thomas. 1989. High frequency of ras oncogene activation in all stages of human thyroid tumorigenesis. Oncogene. 4:159-164.

4. Namba, H., S. A. Rubin, and J. A. Fagin. 1990. Point mutations of ras oncogenes are an early event in thyroid tumorigenesis. Mol. Endocrinol. 4:14741479.

5. Suarez, H. G., J. A. du Villard, M. Severino, B. Caillou, M. Schlumberger, M. Tubiana, C. Parmentier, and R. Monier. 1990. Presence of mutations in all three ras genes in human thyroid tumors. Oncogene. 5:565-570.

6. Namba, H., R. A. Gutman, K. Matsuo, A. Alvarez, and J. A. Fagin. 1990. H-ras proto-oncogene mutations in human thyroid neoplasms. J. Clin. Endocrinol. Metab. 71:223-229.
7. Matsuo, K., S. H. Tang, and J. A. Fagin. 1991. Allelotype of human thyroid tumors: loss of chromosome 11 q13 sequences in follicular neoplasms. Mol. Endocrinol. 5:1873-1879.

8. Grieco, M., M. Santoro, M. T. Berlingieri, R. M. Melillo, R. Donghi, I. Bongarzone, M. A. Pierotti, G. Della Porta, A. Fusco, and G. Vecchio. 1990. PTC is a novel rearranged form of the ret proto-oncogene and is frequently detected in vivo in human thyroid papillary carcinomas. Cell. 60:557-563.

9. Herrmann, M. A., I. D. Hay, D. H. Bartelt, Jr., S. R. Ritland, R. J. Dahl C. S. Grant, and R. B. Jenkins. 1991. Cytogenetic and molecular genetic studies of follicular and papillary thyroid cancers. J. Clin. Invest. 88:1596-1604.

10. Levine, A. J., J. Momand, and C. A. Finlay. 1991. The p53 tumour suppressor gene. Nature (Lond.). 351:453-456.

11. Baker, S. J., E. R. Fearon, J. Nigro, S. Hamilton, A. C. Preisinger, J. M. Jessup, P. vanTuinen, D. H. Ledbetter, D. F. Barker, Y. Nakamura, et al. 1989. Chromosome 17 deletions and p53 gene mutations in colorectal carcinomas. Science (Wash. DC). 244:217-221.

12. Baker, S. J., A. C. Preisinger, J. M. Jessup, C. Paraskeva, S. Markowitz, J. K. V. Willson, S. Hamilton, and B. Vogelstein. 1990. p53 gene mutations occur in combination with $17 \mathrm{p}$ allelic deletions as late events in colorectal tumorigenesis. Cancer Res. 50:7717-7722.

13. Gaidano, G., P. Ballerini, J. Z. Gong, G. Inghirami, A. Neri, E. W. Newcomb, I. T. Magrath, D. M. Knowles, and R. Dallafavera. 1991. p53 Mutations in human lymphoid malignancies associated with Burkitt lymphoma and chronic lymphocytic leukemia. Proc. Natl. Acad. Sci. USA. 88:5413-5417.

14. Slingerland, J. M., M. D. Minden, and S. Benchimol. 1991. Mutation of the 53-gene in human acute myelogenous leukemia. Blood. 77:1500-1507.

15. Takahashi, T., N. M. Nau, I. Chiba, M. J. Birrer, R. K. Rosenberg, M. Vinocour, M. Levitt, H. Pass, A. F. Gazdar, and J. D. Minna. 1989. p53-A frequent target for genetic abnormalities in lung cancer. Science (Wash. DC). 246:491-494.

16. Takahashi, T., D. D’Amico, I. Chiba, D. L. Buchhagen, and D. Minna. 1990. Identification of intronic point mutations as an alternative mechanism for p53 inactivation in lung cancer. J. Clin. Invest. 86:363-369.

17. Hollstein, M. C., R. A. Metcalf, J. A. Welsh, R. Montesano, and C. C. Harris. 1990. Frequent mutation of the p53 gene in human esophageal cancer. Proc. Natl. Acad. Sci. USA. 87:9958-9961.

18. Davidoff, A. M., B. J. M. Kems, J. D. Iglehart, and J. R. Marks. 1991. Maintenance of p53 alterations throughout breast cancer progression. Cancer Res. 51:2605-2610.

19. Hsu, I. C., R. A. Metcalf, T. Sun, J. A. Welsh, N. J. Wang, and C. C. Harris. 1991. Mutational hotspot in the p53 gene in human hepatocellular carcinomas. Nature (Lond.). 350:427-428.

20. Bressac, B., M. Kew, J. Wands, and M. Ozturk. 1991. Selective G to T mutations of $\mathrm{p} 53$ gene in hepatocellular carcinoma from southern Africa. Nature (Lond.) 350:429-431.

21. Sidransky, D., A. Voneschenbach, Y. C. Tsai, P. Jones, I. Summerhayes, F. Marshall, M. Paul, P. Green, S. R. Hamilton, P. Frost, and B. Vogelstein. 1991. Identification of p53 gene mutations in bladder cancers and urine samples. Science (Wash. DC). 252:706-709.

22. Marks, J. R., A. M. Davidoff, B. J. Kerns, P. A. Humphrey, J. C. Pence, R. K. Dodge, D. L. Clarkepearson, J. D. Iglehart, R. C. Bast, and A. Berchuck. 1991. Overexpression and mutation of p53 in epithelial ovarian cancer. Cancer Res. 51:2979-2984.

23. Nigro, J. M., S. J. Baker, A. C. Preisinger, J. M. Jessup, R. Hostetter, K. Cleary, S. H. Bigner, N. Davidson, S. Baylin, P. Devilee, et al. 1989. Mutations in the p53 gene occur in diverse human tumour types. Nature (Lond.). 342:705708.

24. Ledent, C., J. Dumont, G. Vassart, and M. Parmentier. 1991. Thyroid adenocarcinomas secondary to tissue-specific expression of SV40 large T antigen in transgenic mice. Endocrinology. 129:1391-1401.

25. Lane, D. P., and L. V. Crawford. 1979. T-antigen is bound to host protein in SV40-transformed cells. Nature (Lond.). 278:261-263.

26. Linzer, D. I. H., and A. J. Levine. 1979. Characterization of a 54K dalton cellular SV40 tumor antigen present in SV40 transformed cells and in uninfected embryonal carcinoma cells. Cell. 17:43-52.

27. Fagin, J. A., S. H. Tang, K. Matsuo, B. Sharif, and R. Schreck. 1991. A human papillary thyroid carcinoma cell line abundantly expresses a platelet-derived growth factor B-like protein. Clin. Res. 39:207A. (Abstr.)

28. Estour, B., A. J. Van Herle, G. J. F. Juillard, T. L. Totanes, R. S. Sparkes, A. E. Juliano, and H. Klandorf. 1989. Characterization of a human follicular carcinoma cell line (UCLA RO 82 W-1). Virchows Archiv. B. Cell Pathol. 57:167-174.

29. Davis, L. G., M. D. Dibner, J. F. Battey. 1986. Basic Methods in Molecular Biology. Elsevier, New York. 133-135.

30. Aviv, H., and P. Leder. 1972. Purification of biologically active globin messenger RNA by chromatography on oligothymidylic acid-cellulose. Proc. Natl. Acad. Sci. USA. 69:1408-1413.

31. Feinberg, A. P., and B. A. Vogelstein. 1983. A technique for radiolabelling 
DNA restriction endonuclease fragments to high specific activity. Anal. Biochem. 132:6-13.

32. Harlow, E., N. M. Williamson, R. Ralston, D. M. Helfman, and T. E. Adams. 1985. Molecular cloning and in-vitro expression of a cDNA clone for human cellular tumor antigen p53. Mol. Cell. Biol. 5:1601-1610.

33. Gunning, P., P. Ponte, H. Okayama, J. Engel, H. Blau, and L. Kedes. 1983. Isolation and characterization of full length cDNA clones for human alpha, beta, and gamma actin mRNAs: skeletal but not cytoplasmic actin have an amino-terminal cysteine that is subsequently removed. Mol. Cell. Biol. 787-795.

34. Murakami, Y., K. Hayashi K., and T. Sekiya. 1991. Detection of aberrations of p53 alleles and the gene transcript in human tumor cell lines by singlestrand conformation polymorphism analysis. Cancer Res. 51:3356-61.

35. Orita, M., H. Iwahana, H. Kanazawa, K. Hayashi, and T. Sekiya. 1989. Detection of polymorphisms of human DNA by gel electrophoresis as singlestrand conformation polymorphisms. Proc. Natl. Acad. Sci. USA. 86:2766-2770.

36. Lamb, P., and L. Crawford. 1986. Characterization of the human p53 gene. Mol. Cell. Biol. 6:1379-1385.37.

37. Hollstein, M., D. Sidransky, B. Vogelstein, and C. C. Harris. 1991. p53 mutations in human cancers. Science (Wash. DC). 253:49-53.

38. Chiba, I., T. Takahashi, N. M. Nau, D. D’Amico, D. T. Curiel, T. Mitsudomi, D. L. Buchhagen, D. Carbone, S. Piantadosi, H. Koga, et al. 1990. Mutations in the p 53 gene are frequent in primary, resected non-small-cell lung cancer. Oncogene. 5:1602-1610.

39. Eisenstadt, E., A. J. Warren, J. Porter, D. Atkins, and J. H. Miller. 1982. Carcinogenic epoxides of benzo(a)pyrene and cyclopenta(cd)pyrene induce base substitutions via specific transversions. Proc. Natl. Acad. Sci. USA. 79:19451949.
40. Coulondre, C., J. H. Miller, P. J. Farabaugh, and W. Gilbert. 1978. Molecular basis of base substitution hotspots in Escherichia coli. Nature (Lond.). 274:775-780.

41. Rideout, W. M., G. A. Goetzee, A. F. Olumni, and P. A. Jones. 1990. 5-Methylcytosine as an endogenous mutagen in the human LDL receptor and p53 gene. Science (Wash. DC). 249:1288-1290.

42. Wright, P. A., N. R. Lemoine, P. E. Goretzki, F. S. Wyllie, J. Bond, C. Highes, H. D. Roher, E. D. Williams, and D. Wynford-Thomas. 1991. Mutation of the p53 gene in a differentiated human thyroid carcinoma cell line, but not in primary thyroid tumours. Oncogene. 6:1693-97.

43. Hinds, P. W., C. A. Finlay, R. S. Quartin, S. J. Baker, E. R. Fearon, B. Vogelstein, and A. J. Levine. 1990. Mutant p53 DNA clones from human colon carcinomas cooperate with ras in transforming primary rat cells: A comparison of the 'hot spot' mutant phenotypes. Cell Growth Differentiation. 1:571-580.

44. Gannon, J. V., R. Greaves, R. Iggo, and D. P. Lane. 1990. Activating mutations in $\mathrm{p} 53$ produce a common conformational effect. A monoclonal antibody specific for the mutant form. EMBO (Eur. Mol. Biol. Organ.) J. 9:15951602.

45. Raycroft, L., H. Wu, and G. Lozano. 1990. Transcriptional activation by wild-type but not transforming mutants of the p53 anti-oncogene. Science (Wash. DC). 249:1049-1051.

46. Kern, S. E., J. A. Pietenpol, S. Thiagalingam, A. Seymour, K. W. Kinzler, and B. Vogelstein. 1992. Oncogenic forms of p53 inhibit p53-regulated gene expression. Science (Wash. DC). 256:827-830.

47. Michalovitz, D., O. Halevy, and M. Oren. 1991. p53 mutations: gains or losses? J. Cell. Biochem. 45:22-29.

48. Fearon, E. R., and B. Vogelstein. 1990. A genetic model for colorectal tumorigenesis. Cell. 61:759-767. 